\title{
Do You Want to Know What I Learned? Using Informational Trade Books as Models to Teach Text Structure
}

"Do you want to know what I learned in school today?" "Sure," replied Juan's mother. "Today our teacher read us a book about dinosaurs. We learned how their footprints can become a fossil... and how some had three toes... and how some of them wandered around in herds!" " Slow down Juan! Tell me that again, a little bit slower, so I can understand what you are saying."

Juan is not unlike most young children in his love of informational books. When asked which books they would "like to have to keep," $84 \%$ of first-grade children chose informational texts when given a choice of many different types and genres of children's picture books (Mohr, 2003). When Nell Duke (2000) reported her findings that children either read or wrote informational text an average of 3.6 minutes per day in first-grade classrooms, the result was a proverbial "whack up-side the head" for publishers, researchers and classroom teachers alike in the field of literacy. Why was this finding so shocking? Neuman (2001) seemed to capture the problem well. She lamented the fact that many teachers were not building domains of deep, interesting, and valuable knowledge for children. Fortunately, today, unlike what was reported at the turn of the millennium, teachers and children have access to a wide variety of recently published informational trade books of high quality (Casbergue \& Plauché, 2003). But even more importantly, teachers have been encouraged to focus their reading instruction on what Alexander (1997) called "knowledge seeking” by using informational books as a part of regular reading instruction (Alexander \& Jetton, 2000; Dreher, 2003; Duke, 2004; Guthrie, Hoa, \& Wigfield, 2007; Reutzel, Smith, \& Fawson, 2005). 
The increased use of informational text, although commendable, brings with it special comprehension demands for classroom teachers and young students (Alexander \& Jetton, 2000; Sanders \& Schilperoord, 2006). McCutchen, Teske, \& Bankston (2007) point out that, "the genre [expository, narrative, or mixed] of the text imposes a structure on the organization of ideas within the text, and when necessary, on the organization of knowledge itself' (p. 464). The unfamiliar structure of expository texts, unlike narrative texts, has long been shown to pose difficulties for readers and writers alike (Farnan \& Dahl, 2003; Graesser, Golding \& Long, 1991; Zabrucky \& Ratner, 1992). The explanations for the differences in children's awareness of expository and narrative text structure are several. One explanation suggests that narrative texts contain more familiar content (Graesser, et al., 1991). Another explanation suggests that children have many more experiences at home and in school with narrative texts (Duke, 2000). Yet another explanation suggests that sensitivity to text structures may be developmental (Englert \& Thomas, 1987). There is one thing for certain-little research has focused on teaching expository text structure to young children as a means for improving their comprehension of informational texts (Hall, Sabey \& McClellan, 2005; Kucan \& Beck, 1997; Williams, 2005).

We have three purposes for this article. First, we give a status report on the research about teaching expository text structure to young children to improve their comprehension. Second, we describe examples of "well-structured" expository trade book titles to be used for teaching young children text structure. Third, we describe the development and implementation of an explicit text structure lesson plan for teaching text structure to third graders using expository trade books as models.

\section{What does the research say about teaching primary-aged readers expository text} structure? 
In the past few years, three experimental studies have focused upon improving primary grade students' reading of expository texts using text structure as a comprehension strategy. In the first of these three studies, Williams (2005) investigated the effects of text structure instruction on the expository text reading of 128 randomly assigned struggling second-grade readers in 10 intact classrooms in three schools in New York City public schools. Four classrooms were assigned to the text structure instruction treatment, four classrooms were assigned to a content instruction treatment, and two classrooms were assigned to no treatment. Williams (2005) found the text structure group scored significantly higher than either of the other two groups (content instruction or no instruction), not only on the instructed paragraph but also on transfer paragraphs. These findings indicated that text structure instruction with second grade struggling readers using expository texts was effective and that students had transferred what they had learned to the comprehension of novel texts.

Similarly, Hall, Sabey, \& McClellan, (2005) in the second of three studies, investigated the effect of teaching text structure to 72 randomly assigned second-grade students in five classrooms in one school in the Mountain West. In this study, students were assigned to one of three treatment conditions: 1) text structure instruction, 2) content instruction, and 3) no instruction. All instruction occurred within 20 homogeneously grouped guided reading groups. The findings of this study suggest that text structure is an effective strategy for promoting expository text comprehension among normally developing readers in second grade, and that young children benefit from reading and studying text structure in well-structured texts.

In the final study of the three reviewed here, Reutzel, Smith, \& Fawson (2005) investigated teaching 80 randomly assigned second-grade students to use single or multiple comprehension strategies while reading science information books. One of the strategies used in 
the multiple strategy treatment was text structure instruction coupled with the use of graphic organizers. This study provided additional evidence that teaching text structure, when combined with other effective comprehension strategies into a set of strategies, positively impacts secondgrade students' acquisition of content knowledge from text. Students who were taught a set of strategies produced more elaborated retells for both near and far transfer texts than students who were taught a single strategy that did not include text structure instruction or graphic organizers that re-represented text structure. From these three true, random experimental studies, it appears that teaching young children the text structures found in expository texts is not only possible, but also quite effective in improving comprehension as measured by answering questions, summarizing, and retelling. Williams (2005) and Hall, Sabey, \& McClellan (2005) also note that text structure instruction is most effective when students receive such instruction in wellstructured examples of various text structures.

When presented with these findings, many teachers of young children are interested in teaching their students text structure lessons to improve their comprehension of informational or expository texts but consistently raise two concerns about how to do so. First, teachers often comment that they do not have the time to search for "well-structured" texts for teaching specific expository text structures to young children. Second, teachers also often comment that they have not been shown how to construct effective lessons for conveying text structure knowledge to young children. Consequently, we turn our attention now to teachers' first concern and the second purpose of our article - providing descriptions of "well-structured" expository trade book titles to be used for teaching young children various text structures.

\section{What are some "well-structured" expository trade books for teaching primary grade children text structure?}


We have selected high-quality informational trade books that can serve as models of four main text structures: description/list, cause and effect, comparison/contrast, and order/list. This is only a small sample of what is available but will help classroom teachers get started in the important work of teaching younger readers about several text structures used by authors of engaging expository trade books.

\section{Description/List Structure}

Books that use a description/list structure have sections with main ideas followed by elaborations on those main ideas, which are sometimes divided into subsections (Simonsen, 2004).

In Hello, Bumblebee Bat by Darrin Lunde (2007), instead of traditional main idea sentences, the author has written each page of this book so that it asks a question such as, "Bumblebee Bat, what do you look like?" Each question is followed by several simple sentences that answer the question. Similar to Hello, Bumblebee Bat, Meet the Meerkat (2007), also by Lunde, poses questions, which serve as main idea sentences. Supporting details follow as an answer to each question.

Through a combination of sentences that state the main idea, supporting detail sentences, pictures and labels, The Vegetables We Eat by Gail Gibbons (2007) describes the eight groups of vegetables: leaf, bulb, flower bud, root, tuber, stem, fruit, and seed. Two other main topics, "Growing Your Own Vegetable Garden" and "Great Big Vegetable Farms," are treated similarly with main ideas and supporting detail in both words and illustrations with labels.

In It's a Butterfly's Life by Irene Kelly (2007), each page has a clear main idea followed by supporting details. Main ideas include: butterflies have three main body parts, how butterflies 
fly, migration of butterflies, reproduction, and metamorphosis. Each main idea is supported by interesting details and detailed illustrations with labels.

An Egg is Quiet (2006) and A Seed is Sleepy (2007) by Dianna Aston, illustrated by Sylvia Long, both have two-page spreads on which a thesis statement such as "A seed is fruitful" appears in large print followed by a short paragraph that supports it. Illustrations with labels provide further elaboration.

In Slippery, Slimy Baby Frogs (2006), Sandra Markle writes general statements, such as "Some baby frogs do get special care from their parents while they're growing up," which are followed by descriptions of particular species of frogs and how they care for their young.

About Habitats: Deserts, by Cathryn Sill (2007), has three main ideas, each of which is stated on an introductory page and elaborated through several supporting detail sentences, each also appearing on a separate page of the book.

In Exploding Ants: Amazing Facts about How Animals Adapt, Joanne Settel (1999) provides intriguing subheadings like "A Disgusting Disguise" and "Murderous Nest Mates" which introduce several paragraphs that describe and explain phenomena from the natural world such as camouflage and brood parasites.

Face to Face with Caterpillars by Darlyne A. Murawski (2007) begins with an introductory chapter that uses a sequence text structure, but the subsequent chapters, "Eating Machines" and "Self-Defense" are written using a descriptive text structure to explain what caterpillars eat and how they protect themselves from threats.

Super Swimmers: Whales, Dolphins, and Other Mammals of the Sea by Caroline Arnold (2007) effectively uses subheadings, main idea sentences, and elaboration to present information about many characteristics of sea mammals. 


\section{Cause and Effect Structure}

In texts that follow a cause and effect structure, the author presents the results of an event and the reasons that the event occurred (Simonsen, 2004).

Cactus Hotel by Brenda Guiberson (1991) follows a cause and effect chain of events structure, beginning with fruit falling from a saguaro cactus. This leads to the planting of a new saguaro, its subsequent growth to maturity at 50 feet tall and 150 years old when it serves as a home for birds, insects, packrats, and bats. After falling over at 200 years, it becomes a home for scorpions and millipedes and provides shade for desert reptiles.

In A River Ran Wild by Lynne Cherry (1992), the gradual pollution and reclamation of the Nashua River is explained in terms of cause and effect. For example, clear cause and effect is shown in these two sentences: "Chemicals and plastic waste were also dumped into the river. Soon the Nashua's fish and wildlife grew sick from this pollution."

\section{$\underline{\text { Comparison/Contrast Structure }}$}

In texts that follow a comparison/contrast structure, two or more objects, events, people, or places are described in terms of their similarities or differences (Simonsen, 2004).

Snakes: Biggest! Littlest! by Sandra Markle (2005) compares small snakes such as the garter snake to large snakes such as the reticulated python. Similarities of snakes are also explained.

The Journey: Stories of Migration by Cynthia Rylant (2006) compares the migration patterns of gray whales, American silver eels, monarch butterflies, caribou, and terns.

Steve Jenkins, well-known for his paper collage illustrations, compares the origins, development, and behaviors of dogs and cats in Dogs and Cats (2007). He treats the subjects separately, but each gets equal importance because of the structure of the book. One cover and 
one half of the book feature dogs. To read about cats, the reader flips the book over and the other cover and other half of the book features cats. In the middle two page spread, both dogs and cats are featured and a paragraph headed "Friends or enemies" focuses on each animal separately.

\section{Order/Sequence Structure}

Texts that follow an order or sequence structure explain the steps of a process or the order of a sequence of events (Simonsen, 2004).

Pumpkins by Ken Robbins (2006) is a photographic essay that recounts the growth of a pumpkins from first planting to carving and the rotting of the few left to die on the vine, whose seeds go on to make more pumpkins for the next year.

In Apples by Jacqueline Farmer (2007), the first and longest section of this book is subtitled "Growing Apples" and provides a sequential description of how apple trees are cultivated from rootstock, pollinated, harvested, sorted, and distributed.

Clarabelle: Making Milk and So Much More by Cris Peterson (2007) explains all the steps involved in getting milk from Clarabelle, a Holstein cow. Included is a description of how the cows' manure is turned into electricity, fresh bedding for the cows, and fertilizer for the crops that are grown to feed the cows.

Chimp Math: Learning about Time from a Baby Chimpanzee by Ann Whitehead Nagda and Cindy Bickel (2002) provides a day by day sequence of a baby chimpanzee's growth. Details of growth are represented graphically as well (e.g., a bar graph shows weekly weight gains and daily charts document when the baby chimp woke up, ate, napped, and played).

Team Moon: How 400,000 People Landed Apollo 11 on the Moon by Catherine Thimmesh (2006) the sequence of events that led up to the landing of Apollo 11 is described in vivid detail, including the many test-runs or simulations that preceded the actual landing. 


\section{An Explicit Lesson Plan for Teaching Expository Text Structures Using Trade Books as}

\section{Models}

We now turn to our third purpose - providing a model for effective teaching of text structure. After examining the research literature on teaching text structure, particularly the research by Williams (2005), we developed a template for explicit text structure lessons. Since we could not provide sample lesson plans for all expository text types within the confines of a single article, we focus here on an explicit text structure lesson for teaching order/sequence text structure. The explicit text structure lesson plan model for teaching order/sequence text structure included the use of an order/sequencing graphic organizer with sentence strips that were placed in boxes as shown in Figure 1. The boxes are connected by arrows, reinforcing the sequential flow of the ideas. The sentence strips were made to be easily movable by using hook and loop strips. The same effect can be achieved by using sentence strips and a pocket chart.

\section{Figure 1 about here}

The template for an explicit order/sequence text structure lesson plan followed these steps:

- Preview the purpose of the lesson by explaining to the students as follows:

"This book is expository. Expository books are written using different organizations to communicate or tell about information. This book, is written using an order/sequence text structure. Order or sequence text structure tells the order in which events happen or a series of events that happen over time."

- Display the order or sequence clue words and phrases below (large text provided). Discuss how these words indicate the order in which events happen in time. 
- Before reading aloud, display the sentence strips in mixed up order. Read them aloud and ask the students to predict the correct order. As they predict, reorder the strips accordingly.

- $\quad$ Read the target text aloud.

- During the read-aloud, encourage students to notice if their predictions about the order were correct. If they notice an event out of order, discuss the reasons for the necessary change and then make the change accordingly.

- After reading, students independently use a smaller version of the sequencing map to put the sentences in the correct order (be sure to remove the large text sentences from display when children are asked to work independently). Follow up by having the students check their sequence against the correct sequence.

This lesson plan template was used successfully with three different books by a third grade teacher, Mrs. Miller. The books Mrs. Miller read to her students were Cactus Hotel (Guiberson, 1991), Monarch Butterfly (Gibbons, 1989), and Dinosaur Tracks (Zoehfeld, 2007). We focus here on Dinosaur Track, which was the most challenging of the three books because the students had the least amount of background knowledge to draw upon.

Mrs. Miller began the lesson by saying, "We have been working on our sequencing lessons. Who can tell me what sequencing means? Hannah?”

"What order they're supposed to be in. We put it together in the order that seems right." “Right, and we've been reading nonfiction books to learn about sequence. That means the books are..."

"True!" 
“This book, Dinosaur Tracks, uses a sequence structure. Sequence tells a series of events in the order in which they happened."

After reviewing the clue words, Mrs. Miller read aloud the sentence strips in random order.

"I'm going to read them to you. Do you think they're in order already?"

"No!"

The students then provided input about the order of the sentences. During this exchange, students were engaged and participating actively. Charlie thought sentences four and five should be switched because "they make solid layers, and then the top layers come off."

Another student said, "Switch 9 and 10. I think because it says the mud turns into solid stone that should go more up to the top because it seems like if it's solid stone it would probably come after the part about mud."

As Mrs. Miller engaged students in this process of ordering the sentences, she reread the sentences, in their new, provisional order, repeatedly, so that the students could make judgments about the order in which the sentences made the most sense. During this process, it's important to require the students to justify their thinking about why the order of sentences should be changed. Figure 2 shows Mrs. Miller displaying two sentences as the students discuss their order.

\section{Figure 2 about here}

Then Mrs. Miller asked them to think to themselves while she read about whether or not they agreed with the final order they had decided on during this pre-reading phase. "Remember, it's hard for all of us to totally agree until we read the book! If you see something wrong on the chart while I'm reading, raise your hand." While Mrs. Miller read aloud, the students could see the chart and were periodically scanning the predicted order of the sentences to determine 
whether or not they were in the correct order. They stopped seven times during the read-aloud to assess the order and made two changes in the order. For example, at one point, several students chorused, "Yes!" and another student followed up by saying, "Yes, we've got the 'tracks get buried' in the right place." Another student began to say, "Maybe the sand needs...," to which the teacher responded, "Yes, we just read the part about sand. Now the book says, 'A few years later, the tracks get buried in a layer of mud.'” After reading that sentence, a student suggested they trade sentences two and three. The students' engagement was evident as their eyes alternated between studying the chart with the sentences and looking at the book as the teacher held it.

After reading, they checked the order again and decided to make one more change to the order of the sentences. Before Mrs. Miller sent the students off to complete a sequence map individually, she led the class in a choral reading of the sequenced sentences on the large chart. When everyone was satisfied that the sentence strip order was correct and matched the sequence presented in the book, she covered the large sentence strip board and sent the students back to their seats to individually reorder the sentence strips using an $81 / 2$ by 11 inch version of the order/sequencing graphic organizer.

\section{Why is text structure instruction important for younger children?}

When teachers read aloud an informational book, they usually assume that students "get

it." Some do; some don't. In terms of retention of information, research has shown that students retain content from an informational text better than they do when the content is embedded in a story (Jetton, 1994). Pairing a read aloud with an explicit lesson on text structure ensured that more students attended closely to the ideas in the text, dramatically improving students' comprehension and knowledge retention. Work like this can be done in the context of an 
interactive read-aloud during which the teacher models attention to text structure and scaffolds students' understanding of how text structure affects the presentation of ideas in a text (Smolkin \& Donovan, 2001).

In this case, the text structure lesson allowed the teacher to scaffold students' understanding. A pre-reading activity of predicting the order of the sentence strips introduced the students to the major ideas in the book. During reading, by stopping to re-order the sentence strips as major ideas came up, the students' attention was refocused on crucial information. Then, after reading, in an independent activity, students re-ordered the sentence strips individually, allowing them to revisit the major ideas once again. This purposeful redundancy provided multiple exposures to concepts that were presented in through the order or sequence text structure in this informational book.

High quality, well-structured expository trade books can be used as models during explicit lessons on text structure, a practice that goes beyond merely reading and discussing these same books. With continued teacher guidance and practice, students will begin to internalize various expository text structures. As teachers ask students to use graphic organizers as part of their explicit instruction in text structure, students will be better able to effectively order and rerepresent the structure of ideas within expository texts. Eventually, they will be able to assume greater responsibility for comprehending expository texts and engaging successfully in knowledge seeking on their own (Alexander, 1997; Neuman, 2001).

As teachers, we need to capitalize on students' natural curiosity about the world by using more informational text during content area instruction and during literacy instruction. In order to assure that students fully understand these texts, we need to pair the use of high-quality informational texts with well-designed explicit instruction about text structure. In this way, we 
can go beyond a simple read-aloud, which is not as powerful for developing students' understanding and retention of ideas as is explicit instruction about text structure using highquality informational children's books. 


\section{Selected References}

Alexander, P. A. (1997). Knowledge seeking and self-schema: A re-examination of the role of knowledge in learning and instruction. [Editor's Notes] Educational Psychologist, 31, 8992.

Alexander, P. A., \& Jetton, T. L. (2000). Learning from text: A multidimensional and developmental perspective. In M. L. Kamil, P. B. Mosenthal, P. D. Pearson, \& R. Barr (Eds.), Handbook of reading research. Vol. III, (pp. 285-310). Mahwah, NJ: Lawrence Erlbaum Associates.

Casbergue, R. M. \& Plauché, M. B. (2003). Immersing children in nonfiction: Fostering emergent research and writing. In Barone, D. \& Morrow, L. M. (Eds.), Literacy and Young Children: Research-Based Practices, (p. 243-260). NY: Guilford.

Dreher, M. J. (2003). Motivating teachers to read. The Reading Teacher, 56(4), 338-340.

Duke, N. K. (2000). 3.6 minutes per day: The scarcity of informational texts in first grade. Reading Research Quarterly, 35(2), 202-224.

Duke, N. K. (2004). The case for information text. Educational Leadership, 61(6), 40-44.

Englert, C. S., \& Thomas, C. C. (1987). Sensitivity to text structure in reading and writing: A comparison between learning disabled and non-learning disabled students. Learning Disability Quarterly, 10, 93-105.

Farnan, N., \& Dahl, K. (2003). Children's writing: Research and practice. In J. Flood, D. Lapp, J. R. Squire, \& J. M. Jensen (Eds.), Handbook of research on teaching the English language arts, (pp.993-1007). Mahwah, NJ: Lawrence Erlbaum Associates. 
Graesser, A., Golding, J. M., \& Long, D. L. (1991). Narrative representation and comprehension. In R. Barr, M. L. Kamil, P. Mosenthal, \& P. D. Pearson (Eds.), Handbook of Reading Research (Vol. II). New York: Longman.

Guthrie, J. T., Hoa, L. A., \& Wigfield, A. (2007). Reading motivation and reading comprehension growth in the later elementary years. Contemporary Educational Psychology, 32 (3), 282-313.

Hall, K. M., Sabey, B. L., \& McClellan, M. (2005). Expository text comprehension: Helping primary-grade teachers use expository texts to full advantage. Reading Psychology, 26, 211-234.

Jetton, T. L. (1994). Information-driven versus story-driven: What children remember when they are read informational stories. Reading Psychology, 15, 109-130.

Kucan, L., \& Beck, I. L. (1997). Thinking aloud and reading comprehension research: Inquiry, instruction, and social interaction. Review of Educational Research, 67, 271-299.

McCutchen, D., Teske, P., \& Bankston, C. (2007). Writing and cognition: Implication of the cognitive architecture for learning to write and writing to learn. In C. Bazerman (Eds.), Handbook of research on writing: History, society, school, individual, text, (pp. 451470). Mahwah, NJ: Lawrence Erlbaum Associates.

Mohr, K. A. J. (2003). Children's choices: A comparison of book preferences between Hispanic and non-Hispanic first-graders. Reading Psychology: An International Quarterly, 24, 163-176.

Neuman, S. B. (2001). The role of knowledge in early literacy. Reading Research Quarterly, 36, 468-475. 
Reutzel, D. R., Smith, J.A., \& Fawson, P.C. (2005). An evaluation of two approaches for teaching reading comprehension strategies in the primary years using science information texts." Early Childhood Research Quarterly, 20(3), pp. 276-305.

Sanders, T. J. M, \& Schilperoord, J. (2006). Text structure as a window on the cognition of writing: How text analysis provide insights in writing products and writing processes. In C. A. MacArthur, S. Graham, \& Fitzgerald (Eds.) Handbook of Writing Research,(386402). New York: Guilford Press.

Simonsen, S. (2004). Identifying and teaching text structures in content area classrooms. In Content Area Reading and Learning: Instructional Strategies, D. Lapp, J. Flood, \& N. Farnan, eds. Mahwah, NJ: Erlbaum.

Smolkin, L. \& Donovan, C. A. (2001). The contexts of comprehension: the information book read aloud, comprehension acquisition, and comprehension instruction in a first-grade classroom. Elementary School Journal, 102(2), 97-122.

Williams, J. P. (2005). Instruction in reading comprehension for primary-grade students: A focus on text structure. Journal of Special Education, 39(1), 6-18.

Zabrucky, K., \& Ratner, H. H. (1992). Effects of passage type on comprehension monitoring and recall in good and poor readers. Journal of Reading Behavior, 24, 373-391.

\section{Children's Literature References}

Arnold, C. (2007). Super Swimmers: Whales, Dolphins, and Other Mammals of the Sea. Illustrated by P. J. Wynne. Watertown, MA: Charlesbridge.

Aston, D. (2006). Illustrated by S. Long. An egg is quiet. San Francisco, CA: Chronicle Books. Aston, D. H. (2007). Illustrated by S. Long. A seed is sleepy. San Francisco, CA: Chronicle Books. 
Cherry, L. (1992). A river ran wild: An environmental history. New York: Harcourt Brace.

Farmer, J. (2007). Apples. Illustrated by P. L. Tildes. Watertown, MA: Charlesbridge.

Gibbons, G. (2007). The vegetables we eat. New York: Holiday House.

Guiberson, B. (1991). Cactus hotel. New York: Henry Holt.

Jenkins, S. (2007). Dogs and cats. New York: Houghton Mifflin.

Kelly, I. (2007). It's a butterfly's life. New York: Holiday House.

Lunde, D. (2007). Hello, Bumblebee Bat. Illustrated by P. J. Wynne. Watertown, MA: Charlesbridge.

Lunde, D. (2007). Meet the Meerkat. Illustrated by P. J. Wynne. Watertown, MA: Charlesbridge. Markle. S. (2005). Snakes: Biggest! Littlest! Photographs by J. McDonald. Honesdale, PA: Boyds Mills Press.

Markle. S. (2006). Slippery, slimy baby frogs. New York: Walker \& Co.

Murawski, D. A. (2007). Face to face with caterpillars. Washington, DC: National Geographic.

Nagda, A. W. \& Bickel, C. (2002). Chimp math: Learning about time from a baby chimpanzee. New York: Henry Holt.

Peterson, C. (2007). Clarabelle: Making milk and so much more. Honesdale, PA: Boyds Mills Press.

Rylant, C. (2006). The journey: Stories of migration. Illustrated by L. Davis. New York: Scholastic.

Robbins, K. (2006). Pumpkins. New Milford, CT: Roaring Brook Press.

Settel, J. (1999). Exploding ants: Amazing facts about how animals adapt. New York: Simon \& Schuster.

Sill, C. (2007). About habitats: Deserts. Illustrated by J. Sill. Atlanta, GA: Peachtree. 
Thimmesh, C. (2006). Team moon: How 400,000 people landed Apollo 11 on the moon. New York: Houghton Mifflin.

Zoehfeld, K. W. (2007). Dinosaur tracks. New York: HarperCollins. 